\title{
Syllabus Design for Pre-Service English Language Teachers in Spain
}

Diseño de programaciones cortas para futuros profesores de Inglés en España

Gloria Luque Agulló

Departamento de Filología Inglesa. Universidad de Jaén

gluque@ujaen.es

Fecha presentación: 23/01/2017 | Aceptación: 11/12/2017 |Publicación: 22/06/2018

\section{Resumen}

En este artículo se describe el proceso para que los futuros profesores de lenguas extranjeras (inglés) de Educación Secundaria aprendan a diseñar programaciones didácticas adaptadas al contexto español, según la ley educativa más reciente (LOMCE). Considerando la multitud de propuestas de métodos de enseñanza desde principios del siglo XX, y las continuas reformas educativas en España, los futuros profesionales de la enseñanza deben adquirir las competencias y habilidades necesarias para el desarrollo de programaciones que se adapten a las diferentes leyes, al mismo tiempo que se incrementa su autoestima y maestría en el aula.

Palabras clave: era post-método; diseño curricular; programación didáctica; enseñanza de inglés; España

\section{Resum}

En este treball es descriu el procés perquè els futurs professors de llengües estrangeres (anglés) d'Educació Secundària aprenguen a dissenyar programacions adaptades al context espanyol, con la llei educativa actual (LOMCE) Considerant la multitud de propostes de mètodes d'ensenyança des de principis del segle XX, i les contínues reformes educatives a Espanya, els futurs professionals de l'ensenyança han d'adquirir les competències i procediments necessaris per al desenrotllament de programacions que s'adapten a les diferents lleis, alhora que incrementa la seua autoestima i la seua mestria en l'aula.

Paraules clau: era post-mètode; disseny del pla d'estudis; programació didàctica; ensenyament d'anglès, Espanya

\begin{abstract}
This paper describes the steps involved in designing educational programs for pre-service English language teachers in Secondary education within the Spanish context, following the current educational law (LOMCE). Considering the century-long search for the best method within TEFL (Teaching English as a Foreign Language), and the continuous reforms of educational laws in Spain, pre-service teachers must learn the competences and skills essential for designing of their own teaching program. The series of steps described here will enable teachers to show accountability to educational authorities and increase their self-confidence, subsequently improving their craft in the language classroom.
\end{abstract}

Key Words: postmethod era; syllabus design; educational program; English teaching; Spain

\section{Introduction}

The search for the best method has been, and still is, in some contexts, a constant issue in Teaching English as a Second/Foreign language (TESOL/TEFL) (Hall, 2016). Along with each method, a series of distinctive syllabi has been proposed to practitioners, including an innovative set of techniques, strategies and materials which have attempted to guarantee success in all classroom situations 1 .

1 Following Tejada, Perez and Luque (2006) Method is a general term including notion of language, notion of learning, teaching approach, design and procedures. Syllabus/syllabi is a synonym for programme, but it contains what is to be taught with a clear reference to the selection and grading of content. Curricular 
However, "transmission-oriented methods" (Ahmadian and Rad, 2014, p.593) have produced disenchantment, as no individual method has proven to be entirely successful (Kumaradivelu, 2006; Hall, 2016). This current dissatisfaction has arisen because the implementation of the different language teaching methods has always been a top-down process in which teachers and learners were not considered. Second, some learners learn independently of the method used, whereas others do not (Ahmadian and Rad, 2014; Kumaravadivelu, 2001, 2006). Third, results indicate that frequently, teachers who believe they are following a method do not actually adhere to this particular method in real classroom situations (Kumaravadivelu, 2002). However, even if teachers may fail to put specific methods into practice, they "are successful in achieving learning outcomes" (Can, 2012, p.1). Consequently, as theory does not reflect the classroom reality, the search is focused now on "an alternative to method rather than an alternative method" (Hashemi, 2011, pp.140-1), or, in other words, the "postmethod era" (Ahmadian and Rad, 2014; Can, 2012; Kumaradivelu, 2001, 2006), in answer to these shortcomings. However, even if experienced teachers can make use of their own expertise for devising their particular syllabus in their daily lessons, how can pre-service language teachers, trained in the belief that the ideal method exists, face classroom practice? They require a set of principles to start from, some sort of syllabus to guide them in the shifting sands of the postmethod pedagogy, or, alternatively, they might "ignore the syllabus and allow the textbook designers decide for them" (Hadley, 1998, p.212).

\section{Shifting educational laws in Spain}

Another issue to consider in addition to the lack of an ideal method is the accountability with the school administration and educational policies. Showing accountability means following the path established by educational authorities, implementing those elements/methodologies in the classroom and informing those authorities that one is ascribing to them. More often than not, accountability is dependent on following ever-changing educational laws determined by who is in power. Senior teachers are aware of the fact that incoming governments usually promote new educational laws (Bolivar and Domingo, 2006; Tiana, Moya and Luengo, 2011), and they have the tools and strategies to accomplish what is required of them without abandoning effective methodologies. However, pre-service teachers are faced with a number of decisions related to the balance between these fluctuating educational policies they are answerable to and the pedagogical theories they have studied.

In Spain, the three last decades have seen several fundamental educational reforms. Leaving aside the

design, on the other hand, is a relatively new term which sometimes substitutes both words, programme and syllabus, including other pedagogical aspects such as objectives, linguistic content, activities, learner roles, teacher roles, and the role of instructional materials. Due to the ambiguity of use of the different terms and their translated version by different authors (Nation and MacAllister, 2009), in this paper the words syllabus and educational program will be used as synonyms, whereas the term lesson plan, which involves a higher degree of concreteness, will also be used when the elements of the two previous terms are delineated for particular classroom contexts. For a visual representation, see also Figure 1.
1970 General Education Act, in place for thirty years (Bolivar and Domingo, 2006), the LOGSE (Ley de Ordenación General del Sistema Educativo) was conceived in 1990. Twelve years later, and with a new government, the 2002 Education Act (LOCE, ley Orgánica de Calidad de la Educación) was created to overcome the failure of the previous law, although it was never enforced. Then again, four years later, the implementation of the LOCE was discontinued and a new Reform Law, the LOE (Ley Orgánica de Educación, 2006) was elaborated, to "counter-counter reform the 2002 changes" (Bolivar and Domingo, 2006, p.342). This law was never abrogated, but in 2015, again a new law was passed, the LOMCE (Ley Organica para la Mejora de la Calidad Educativa, Royal Decree 1105/2015, revised in the Royal Decree 310/2016, July 29th), creating a situation in schools which has been, for students and specially for teachers, very misleading, as in the period 2015-16, in some Spanish communities (i.e Andalucía), the two most recent laws were implemented simultaneously, the LOE, in even courses, and the LOMCE, in uneven ones. Therefore, teachers have had to prepare different syllabi depending on the level. This uncertainty shows the current situation in the Spanish educational system, particularly when educational research (Bolivar and Domingo, 2006; Fullan, 2007) has shown that change of educational laws does not bring a change in the school culture or in performance standards. A deeper transformation is required, involving economic, educational and cultural issues.

The words of Bolívar and Domingo (2006, p.340) "compulsory secondary education has become a political battlefield" still apply ten years later. Nowadays, this is the arena in which ELT (English Language Teaching) courses must prepare pre-service teachers.

\section{Syllabus design in the postmethod era}

Language Teaching Education must provide teachers with the techniques, strategies and procedures of specific methods. Namely, novice teachers need to be acquainted with a set of guiding principles, that is to say, an approach or method (Ahmadian and Rad, 2014; Richards and Rodgers, 2014), which guarantees they can cope with a classroom, improving their self-confidence and giving them "an instructional compass" (Hadley, 1998, p.212). Different methods or approaches are implemented through syllabus design ${ }^{2}$, which constitutes a middle ground between what the ELT theory proposes and actual classroom practice (see Figure 1).

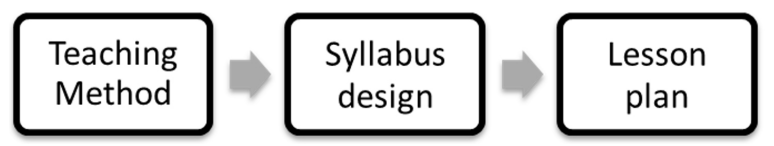

Figure 1. Visual representation of the connection between teaching method, syllabus and lesson plan, from a more general planning process to a more specific one, adapted to classroom contexts

Although there is no definition of an ideal ELT syllabus that meets the different leaning needs of the different learners (Smriti and Jha, 2015), a syllabus can be defined as the selection and ordering of what is to be

\footnotetext{
2 Several terms are associated to syllabus design, such as curriculum design, curriculum development, and (lesson) planning.
} 
taught (Widdowson, 1990). Yalden (1983) indicates that it is an instrument to fit the needs of learners with classroom activities, while Brumfit (1984) considers it as a document of administrative convenience. In short, a syllabus should outline the goals and objectives of the course, prerequisites, evaluation scheme and ideally, the references (Kearsley and Lynch, 1996). Moreover, a syllabus reveals more than it teaches, because "it is also a philosophical statement about learning and cognition" (Hadley, 1998, p.214), in the sense it involves a set of beliefs which influences the educational focus, the selection of materials and the way those materials will be presented and organized. In conclusion, it reflects the views designers hold on control, language and pedagogy. Several dichotomous categories of ELT syllabi can be found in the literature (Nunan, 1988; Skehan, 1996; White, 1988), depending on their focus: product vs. process syllabi, synthetic vs. analytic, type A vs. type B, and linear vs. cyclical ones.

More recently, Richards (2013) has also established a further distinction between forward, central or backward design. Forward design begins with the selection of contents, then deals with methodological issues and finishes setting learning outcomes, ascribing to a traditional or type A syllabus/educational program. In central design, methodology is the core element, later addressing contents and learning results. Finally, backward designs, such as the one established by the Common European Framework of Languages (Council of Europe, 2001), focuses on what the learner is able to do, namely, outcomes or results, and decisions on content and methodology are then set up in accordance to those expected learning outcomes.

Every type of syllabus involves positive aspects and shortcomings. Additionally, individual teachers and learners might be more suited to any of these types, depending on their cognitive style or other individual differences (Ehrman, Leaver and Oxford, 2003; Winke, 2007). The option put forward by TEFL (Teaching as a Foreign Language) literature is to implement a negotiated or eclectic syllabus (Can, 2012; Kumaravadivelu, 2001, 2006; Nation and Macalister, 2009; Richards, 2013), which does not involve a return to structural grammars or traditional methodologies. In negotiated syllabi, teachers and learners are both involved in those decisions concerning content, materials, methodology and evaluation, reaching a consensus that may lead to an idiosyncratic syllabus which does not conform to the characteristics of any specific syllabus design.

Regardless of the philosophy underlying syllabi, their design involves long-term and short term planning. Depending on the amount of information detailed and the time extension in which the program is expected to develop, most teachers will engage in yearly, term, unit, weekly and daily lesson planning (Farrell, 2002, p.30). The longer design asserts which contents (language) will be taught, and how will this content organized throughout the course, including procedures, classroom dynamics and techniques, for short, the methodology. Moreover, it should be guided by current educational policies. Additionally, syllabus design may involve a short-term scheme, intended for one or several sessions, in which a restricted set of contents or language items are structured or a topic is developed. This short term planning constitutes a concrete proposal of the three general issues mentioned above: what to teach, how to teach and how to establish whether those contents have been processed (see Figure 2).

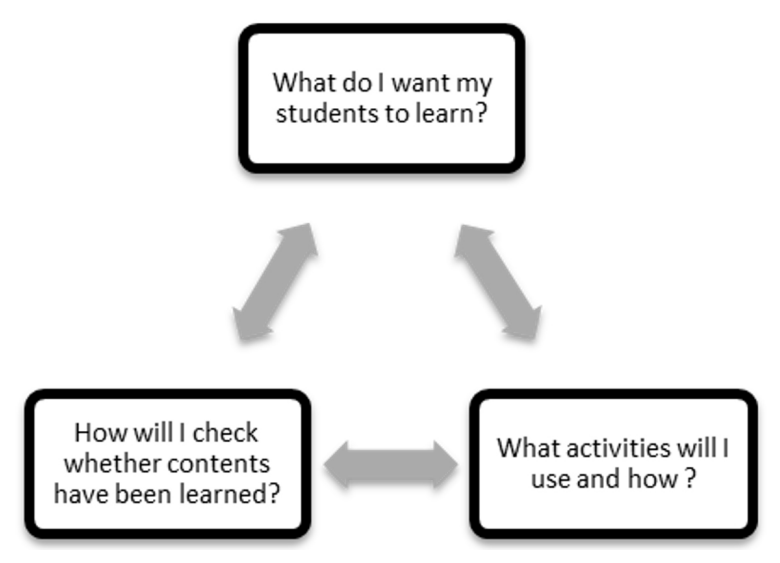

Figure 2. Questions to be considered for short term planning

However, the answer to these three questions depends on the type of syllabus chosen, which reflects particular methods and as a consequence will affect pedagogical practices.

\section{Syllabus design: a guideline}

Given the myriad of methods and syllabi (Richards and Rodgers, 2014), and also the fact that, according to research (Can, 2012; Kumaradivelu, 2001; 2006), teachers do not really implement particular methods in classroom situations even if they are successful in maximizing learning outcomes, what would be the use of a guideline for a lesson plan?

Novice teachers need a guide and they also need to know how to construct/create this guide. Even though there are many excellent printed and online resources for teachers, these materials have to be adapted to the teachers and learners' needs. Textbook designers cannot -or should not- decide what happens in the classroom. Additionally, the lack of a syllabus cannot be justified in educational terms, as there would be no way to show accountability.

Therefore, a guide for a brief syllabus or lesson plan is provided below (Table 1). To make this guide accountable to school authorities, it follows the most recent educational law passed in Spain, the LOMCE, comparing it with the previous one (LOE), and making a distinction between the two when there is a relevant difference. 


\begin{tabular}{|c|c|c|}
\hline & LOE & LOMCE \\
\hline 1 & \multicolumn{2}{|c|}{ Topic } \\
\hline 2 & \multicolumn{2}{|c|}{ Justification } \\
\hline 3 & \multicolumn{2}{|c|}{ Background information and contextualization } \\
\hline 4 & Core competences & Key competences \\
\hline 5 & General objectives & \\
\hline 6 & \multicolumn{2}{|c|}{ Didactic objectives } \\
\hline 7 & \multicolumn{2}{|c|}{ Contents } \\
\hline 8 & Cross-cultural issues & Cross-cultural elements \\
\hline 9 & \multicolumn{2}{|c|}{ Interdisciplinary } \\
\hline \multirow[t]{5}{*}{10} & \multicolumn{2}{|c|}{ Methodology } \\
\hline & \multicolumn{2}{|c|}{ (Temporalization } \\
\hline & \multicolumn{2}{|c|}{ Attention to diversity } \\
\hline & \multicolumn{2}{|c|}{ Materials } \\
\hline & \multicolumn{2}{|c|}{ Step-by-step account) } \\
\hline 11 & \multicolumn{2}{|c|}{ Evaluation } \\
\hline 12 & & Learning standards \\
\hline 13 & \multicolumn{2}{|c|}{ References and resources } \\
\hline
\end{tabular}

Table 1. Sections of a lesson plan. Blank spaces involve that the Law does not include this element

- The topic, or first element, is a descriptive but brief title given to the lesson plan. It must have a connection with educational laws, but also be relevant for students. It can be selected from a textbook, by the students or by the teacher, and it synthesizes, in a few words, the contents that will be considered. Very common examples may be Holidays, Past experiences, Explorers... but creativity in the choice of topic may increase learners' interest and motivation.

- The justification involves an explicit argumentation of the reasons the topic must be developed. In other words, it shows the contribution of the unit to the educational aims in the curriculum. It should connect its content with the information provided by educational documents (LOE; LOMCE). Additionally, it can also be related to the contents available in the Common European Framework of Languages (CEFR) (Council of Europe, 2001). Other sources can also be used to justify it, including the teacher or syllabus designer.

- $\quad$ Background information refers to the temporal and spatial context where the teaching and learning process is expected to occur, including the number of students, type of classroom and school, resources in that classroom-school, the level of students, their features and point in time where the unit is included within the general planning of the course. Additionally, it should consider a needs analysis, in which the learners' previous knowledge and recent work are also outlined.

- Competences constitute a relatively novel element in Spanish educational laws, as only the LOE and the LOMCE have included them as explicit elements of curriculum design. Although the concept of competence is not new ${ }^{3}$ and definitions abound, here they will be considered as the set of concepts/contents, procedures, attitudes and abilities acquired as a result of the learning process in multiple contexts. Within this framework, students are not only expected to learn different objectives, contents, and use of materials, but also professional and scientific abilities -competenceswhich should be the outcome developed from those contents, and which are essential for successfully implementing a job in their prospective labour market (Ramos and Luque, 2010). The difference between an educative model organized around objectives -as in previous educational laws- and another that considers competences is that new abilities are of a higher order nature (i.e. for rapid adaptation, coordinated use of interconnected strategies, etc.), requiring a deep conceptual change and a very complex adaptation to specific, changing environments (Ramos and Luque, 2010; Tiana, Moya and Luengo, 2011). In other words, the cognitive demands established by competences are more complex than when learning is organized around contents or objectives.

Table 2 shows the competences included in the two latest educational laws are enumerated and compared. Several differences can be stated. Competences differ in number (eight for the LOMCE and seven for the LOE), in description (see the first four phrasings in Table 2), and also in application. In the LOMCE, all competences must be achieved through the different learning activities both in Secondary education and also in non-compulsory education (Bachillerato), whereas the LOE makes them obligatory only for compulsory education.

\begin{tabular}{|l|l|}
\hline LOE & LOMCE \\
\hline $\begin{array}{l}\text { Competence in one's mother tongue and in a } \\
\text { foreign language }\end{array}$ & Linguistic Communication \\
\hline Mathematical competence & $\begin{array}{l}\text { Mathematical competence and key } \\
\text { competences in science and technology }\end{array}$ \\
\hline Digital and technological competences & Digital competence \\
\hline $\begin{array}{l}\text { (interpersonal and intercultural) social and civic } \\
\text { competence }\end{array}$ & Social and civic competences \\
\hline Cultural and artistic competence & Cultural expressions and artistic awareness \\
\hline Learning to learn & Learning to learn \\
\hline Autonomy and personal initiative & Enterpreunership and personal initiative \\
\hline $\begin{array}{l}\text { Competence in knowledge and interaction with } \\
\text { the physical world }\end{array}$ & \\
\hline
\end{tabular}

Table 2. Competences according to the two most recent educational laws in Spain

- $\quad$ Pedagogical/didactic objectives respond to one of the questions posed above, in Figure 2, what to teach, establishing the intentions supporting the planning and the implementation of those activities needed for the attainment of the goals selected for the unit. They

3 There are many definitions of Competence, and the term has been widely used in a number of disciplines. In the field of $\mathrm{SL} / \mathrm{FL}$, Chomsky (1965) was the first linguist to distinguish competence vs. performance, but Hymes (1967), Cummins (1979), Canale (1983) and then Bachman (1990) also referred to the notion of "an inner knowledge of language" which cannot be observed except through performance, or, in other words, through communication. The Common European Framework (Council of Europe, 2001) and the current laws of education in Spain have also introduced its use, probably influenced by educational psychology. 
constitute a guide for selecting contents and activities, and also for evaluation criteria. As shown in Table 1, only the LOE documents contemplate general objectives explicitly, whereas the LOMCE includes general stage objectives, but does not refer to course objectives. However, in practical terms, didactic (specific) objectives must be set for the units. They must be closely related to contents, competences and general objectives (conveyed in the Law), but must also be reachable.

They have to be organized in terms of communicative functions or notions, and should be formulated using the infinitive form. They may include conceptual or declarative knowledge (i.e. to understand, to explain), procedural knowledge (i.e to describe, to use) and attitudinal knowledge (to be aware, to reflect). Additionally, they can be formulated either from the point of view of the teacher or that of the learners, but the two perspectives cannot be combined. Examples developed from the learners' perspective are shown in the table below (Table 3).

\begin{tabular}{|ll|}
\hline Didactic objective & Example \\
\hline Conceptual & $\begin{array}{l}\text { To know vocabulary related to } \\
\text { junk food }\end{array}$ \\
\hline Procedural & $\begin{array}{l}\text { To use expressions related to } \\
\text { likes and dislikes in oral } \\
\text { conversations and in written } \\
\text { documents }\end{array}$ \\
\hline Attitudinal & To respect and understand \\
& peers' viewpoints \\
\hline
\end{tabular}

Table 3. Examples of didactic (or pedagogical) objectives

- $\quad$ Contents consist of the concepts, procedures and attitudes that will be developed throughout the lesson plan. They must be closely linked to general and didactic objectives and competences, and, like objectives, they are set to develop communicative competence. They are organized into four blocks or thematic nuclei, which differ depending on the law (see Table 4). Although their organization in areas is different for the two sets of regulations, the specific contents to be developed in specific syllabi ought to be very similar, as their general aim is identical for the two laws. Whereas the LOE introduced oral and written aspects, including then linguistic and learning to learn issues and finally cultural aspects, the LOMCE has separated oral comprehension from expression, and similarly, written comprehension and expression. Each of these four blocs contemplate strategies, sociocultural aspects and formal linguistic issues (syntactic, discursive, lexical and pronunciation elements). For the units, contents must be formulated using the -ing form or a nominalization (see examples in Table 4).

\begin{tabular}{|c|c|c|c|}
\hline & Example & LOMCE & Example \\
\hline $\begin{array}{l}\text { Listening, speaking } \\
\text { and interacting }\end{array}$ & $\begin{array}{l}\text {-Listening to some } \\
\text { extracts to get the gist } \\
\text { of what is being said } \\
\text {-Expressing } \\
\text { agreement and } \\
\text { disagreement }\end{array}$ & Listening & $\begin{array}{l}\text {-Listening to } \\
\text { some extracts to } \\
\text { get the gist of } \\
\text { What is being said } \\
\text {-Understanding } \\
\text { expressions of } \\
\text { agreement and } \\
\text { disagreement }\end{array}$ \\
\hline Reading and writing & $\begin{array}{l}\text {-Reading, } \\
\text { understanding and } \\
\text { synthesizing the main } \\
\text { arguments of a text } \\
\text { expressing opinion }\end{array}$ & $\begin{array}{l}\text { Speaking } \\
\text { interacting }\end{array}$ & $\begin{array}{l}\text {-Expressing } \\
\text { agreement and } \\
\text { disagreement } \\
\text { using the } \\
\text { adequate } \\
\text { expressions, } \\
\text { vocabulary and } \\
\text { pronunciation }\end{array}$ \\
\hline $\begin{array}{l}\text { Reflection upon the } \\
\text { language and linguistic } \\
\text { awareness }\end{array}$ & $\begin{array}{l}\text {-Using expressions of } \\
\text { agreement and } \\
\text { disagreement } \\
\text {-Employing both } \\
\text { orally and in written } \\
\text { form the vocabulary } \\
\text { of the unit } \\
\text {-Recognizing and } \\
\text { Pronouncing the } \\
\text { stress patterns when } \\
\text { expressing } \\
\text { agreement or } \\
\text { disagreement }\end{array}$ & Reading & $\begin{array}{l}\text {-Reading and } \\
\text { understanding the } \\
\text { gist of several } \\
\text { texts expressing } \\
\text { opinion }\end{array}$ \\
\hline $\begin{array}{l}\text { Sociocultural aspects } \\
\text { and intercultural } \\
\text { awareness }\end{array}$ & $\begin{array}{l}\text {-Recognizing the } \\
\text { cultural differences } \\
\text { between the } L 1 \text { and } \\
\text { the L2 when } \\
\text { expressing } \\
\text { agreement }\end{array}$ & Writing and interacting & $\begin{array}{l}\text {-Synthesizing the } \\
\text { main arguments } \\
\text { of a text } \\
\text { expressing } \\
\text { opinion, using the } \\
\text { adequate } \\
\text { expressions, } \\
\text { vocabulary and } \\
\text { pronunciation }\end{array}$ \\
\hline
\end{tabular}

Table 4. Organization of contents within a lesson plan

- Cross-curricular issues

This section refers to those topics that have to be considered in all the subjects within the curriculum, including the foreign language. In practical terms, it involves that learners, while carrying out tasks/activities aimed at learning the second language, should also listen, speak, read and/or write about one or more of these topics. Generally speaking, teachers are free to decide which unit might include a specific curricular issue. Although both laws include them, some differences in emphasis can be considered. 


\begin{tabular}{|ll|}
\hline LOE & LOMCE \\
\hline Road safety education & Road safety education \\
Environmental education & Consumer's Education \\
Health education & Health education \\
Coeducation & $\begin{array}{l}\text { Coeducation } \\
\text { opportunities for disabled } \\
\text { people, for men \& women) }\end{array}$ \\
Education for peace & Education for peace \\
Moral and civic education & \\
Sexual education & \\
Multicultural education & \\
\hline
\end{tabular}

Table 5. Cross-curricular issues considered in the current and previous law

Additionally, the LOMCE incorporates, for their inclusion in all subjects of the curriculum:

\begin{tabular}{|l|}
\hline Reading comprehension \\
Oral and written expression \\
Audiovisual communication \\
Information and Communication Technologies \\
Entrepreneurship and civic and constitutional education \\
\hline
\end{tabular}

Table 6. Additional cross-curricular issues stated by the LOMCE for all content subjects

- Interdisciplinarity

This constituent refers to the role other subjects in the curriculum may occupy in the activities/tasks developed in the lesson plan. Namely, when learning about how to express directions, the teacher may introduce a map in which students will have to use their spatial abilities, which involves mathematical content. Likewise, if cultural elements are mentioned, some geographical knowledge may be required.

\section{- Methodology}

This section develops aspects related to when and how to teach the intended contents. It must consider issues related to the teaching practice, such as the methodological principles and orientations that will guide the lesson plan, the activities chosen, the classroom dynamics, that is to say, the interaction patterns, their temporalization and sequencing, the materials and resources to be used, and how diversity will be attended (see Figure 3). Different methods involve different lesson developments. Therefore, the methodological beliefs of individual teachers will influence the choice of activities, groupings, materials, and even the sequencing of the selected activities/tasks.

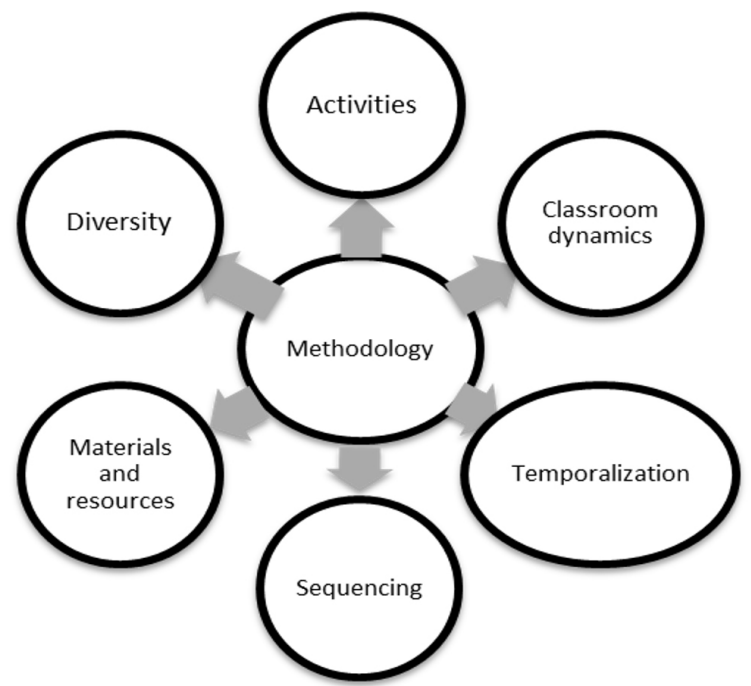

Figure 3. Methodological issues in syllabus design and lesson planning

Activities ${ }^{4}$ constitute the core of the lesson plan, and can be defined as the tools for developing the contents and reaching the objectives (and competences), so they must be consistent with both. They are designed to achieve specific results, outcomes, or learning processes, defining the work to be done. The choice of activity also involves decisions concerning classroom dynamics, that is to say, how the activity will be carried out, individually, in pairs, in groups or the whole classroom, an estimated timing, longer or shorter depending on its complexity, and a set of materials or resources needed to implement the activity. Furthermore, different activities are organized following a sequence, which involves a starting point, a series of transitional steps and a conclusion (see Appendix I).

Additionally, classroom teaching involves diversity 5 , which can be considered from two perspectives: from the point of view of those learners with specific needs of educational support, or those who show different learning paces. In the case of specific needs, three possible situations can occur: students may require special or additional attention; second, they may be gifted; and, third, they may have entered the educative system at a later stage, i.e. immigrants. Students may also show different learning rates. Consequently, lesson designers and teachers must decide which activities will cater for these different situations by designing core, extension and reinforcement activities. Core activities are intended for all learners, and they develop the contents and pedagogical objectives selected for the unit. Extension activities are addressed to students with high intellectual abilities or extremely motivated for learning, while reinforcement activities may be used when core contents are not being achieved or in those cases in which learners need extra practice. Diversity can also be

\footnotetext{
${ }^{4}$ In task-based approaches (see Willis and Willis, 2008), the core of lesson plans are tasks, which include several actions, exercises or steps to achieve a final goal or task. One of the differences between the two terms is that activities do not have to involve a (final or global) purpose, they are considered individual events. The terms exercises and activities can be considered synonyms, whereas tasks involve several actions connected to achieve a final aim, and thus, involve several consecutive steps.

5 See LOMCE (Royal Decree 1105/2014, p. 175) and LOE (Royal Decree 1631/2006, p. 681).
} 
attended by implementing specific techniques, such as using pair-work with students with differing abilities or learning rhythms, selecting the places learners occupy in the class or rearranging classroom desks in activity clusters so that different groups of students complete different activities in a simultaneous way.

\section{- Evaluation}

It is the process in which the teacher and the students ascertain whether objectives initially set for the lesson are being/have been achieved. It controls and regulates the teaching/learning process and assists in acting on the feedback obtained. In general, there are three basic evaluation stages: before the learning/teaching process, or diagnostic evaluation, while this process is taking place, or formative/procedural evaluation, and, third, summative evaluation, which involves a global assessment of the process. In lesson plan evaluation, there may be an optional diagnostic evaluation to check on students' initial knowledge on the contents and objectives to be achieved in the unit, and a formative evaluation, to assess their achievement and act on this information. For the unit, pedagogical objectives must have their corresponding evaluation criteria (what) which will then be evaluated by means of Tools (how), which in turn may include formal tests, teacher's registers/checklists, students' presentations, classroom exercises or homework, among other procedures (see example in Table 7). These tools constitute the different means by which the teacher can establish the marking criteria, attributing a percentage to each evaluation task/procedure.

Additionally, concerning the LOMCE, evaluation criteria must be measured against the Assessable Learning Standards 6 , which explicitly state what students must accomplish (know, understand and do) regarding the learning results, and follow the same thematic nuclei than contents (see Table 4, above). They must be observable, measurable and assessable, but also gradable, to determine the learners' level of achievement (i.e. low, middle, high, complete). Moreover, they must contribute and facilitate the design of standardized and comparable tests. As shown in table seven, there should be a direct correspondence between learning standards, evaluation criteria, didactic objectives and contents.

However, evaluation is not only the process that regulates the learning situation; it should also consider an assessment of the teaching process, including materials/resources used, techniques/activities implemented and finally, teaching practices. In other words, this type of evaluation should incorporate one or more instruments (checklists, rubrics, portfolios) to verify whether the aims and contents set for the lesson were realistic and appropriately chosen and developed in the learners' point of view. The feedback obtained should have a direct implication for the design or adaptation of future lesson plans.

\footnotetext{
${ }^{6}$ The definition is taken and adapted from BOE-A-2015-37, p.
} 172.

\begin{tabular}{|c|c|c|c|}
\hline Didactic objective & valuation criteria & ools & standards \\
\hline $\begin{array}{l}\text { To know } \\
\text { vocabulary related } \\
\text { to junk food }\end{array}$ & $\begin{array}{|lr|}\text { Whether r r r } & \text { the } \\
\text { students } & \text { know } \\
\text { vocabulary } & \text { related } \\
\text { to junk food } & \end{array}$ & $\begin{array}{l}\text {-Classroom exercises } \\
\text { handed out to the } \\
\text { teacher } \\
\text {-Formal test }\end{array}$ & $\begin{array}{l}\text {-(Oral production) } \\
\text { Participates in informal } \\
\text { face to face } \\
\text { conversations, }\end{array}$ \\
\hline $\begin{array}{l}\text { To use } \\
\text { expressions } \\
\text { related to likes and } \\
\text { dislikes in oral } \\
\text { conversations and } \\
\text { in written } \\
\text { documents }\end{array}$ & $\begin{array}{l}\text { Whether the } \\
\text { students are able to } \\
\text { use expressions } \\
\text { related to likes and } \\
\text { dislikes in oral and } \\
\text { written tasks }\end{array}$ & $\begin{array}{l}\text {-Role-play (recorded) } \\
\text {-Participation in } \\
\text { Teacher's blog }\end{array}$ & $\begin{array}{l}\text { and expresses opinions } \\
\text { or personal viewpoints[6] } \\
\text {-(Written production) } \\
\text { Writes brief messages } \\
\text { and notes (SMS, chats) in } \\
\text { which he/she makes brief }\end{array}$ \\
\hline $\begin{array}{l}\text { To respect and } \\
\text { understand peers' } \\
\text { viewpoints }\end{array}$ & $\begin{array}{l}\text { Whether students } \\
\text { are able to respect } \\
\text { and understand } \\
\text { peers' viewpoints }\end{array}$ & $\begin{array}{l}\text { - Teacher's notes on } \\
\text { classroom behavior }\end{array}$ & $\begin{array}{l}\text { related to his/her } \\
\text { everyday activities and } \\
\text { interests, respecting } \\
\text { conventions and courtesy } \\
\text { norms }[7]\end{array}$ \\
\hline
\end{tabular}

Table 7. Example of evaluation process in syllabus design and, specifically, for a lesson plan

\section{- $\quad$ References and resources}

The last element to consider within syllabus design is the listing of references (textbooks, resource books, legal documents) and resources used (to mention a few, internet pages with downloadable worksheets, videos, podcasts, chats, blogs, wikis) both for designing the lesson plan or for carrying out the tasks established.

\section{Conclusions}

As Hadley (1998, p.211) commented 20 years ago, "English Language Teaching is in the mist of another significant paradigm shift". If "the past three decades have witnessed unprecedented changes in the field of syllabus design" (Smitri and Jha, 2015, p.1; Graves, 2016), how can teachers keep updated on designing their own syllabus?

The design of an ideal method, and subsequently, syllabus, has engaged Applied Linguists during the last century, and the challenge still continues. While previously, a succession of methods was created and directed at teachers, nowadays the postmethod era considers that the teacher himself should construct "classroom procedures and principles (...) based on his/her prior and experiential knowledge and/or certain strategies" (Can, 2012, p.2; Hall, 2016). Namely, teachers should be able to create their own syllabus/lesson plan, while at the same time they must show accountability as regards the educational establishment and laws ascertained by the country where they live (Wang and Stelson, 2017). In Spain, this has entailed adapting to several educational reforms in the last thirty years (Bolivar and Domingo, 2006).

Thus, many experienced teachers may find themselves striving to adapt to ever-changing teaching methods and continuous educational reforms. This is also the situation facing prospective language teachers, with the added difficulty of their lack of experience. Consequently, this paper describes a series of procedures that adjust to current methodologies within the field of TEFL and also conform to the current (and shifting) Spanish educational laws (also see Luque, 2017).

This paper (see Table 1 in section 4) constitutes an attempt at describing the steps involved in designing a syllabus, or, for shorter time frames and with more degree of detail, a lesson plan. It includes a comprehensive description of all those elements that teachers should consider in accordance to the Spanish current law (LOMCE) as compared to the previous one (LOE), involving competences, objectives, contents, methodology, evaluation, references and resources. 
Experienced teachers may be disenchanted with an establishment that continuously promotes methodological changes, and they may feel they do not need such a detailed description of all these elements described above. However, both novice and experienced teachers cannot ignore the fact that they must show accountability; that is to say, they must follow the law and also demonstrate they do so (Graves, 2016). Additionally, "clarifying one's internal syllabus is important because a teacher can apply this insight to his or her classroom approach" (Hadley, 1998, p.225), and establishing his/her philosophical base and pedagogical intentions will maximize his/her self-confidence, in turn improving his craft as a language teacher. No teacher should enter a classroom without a clear idea of what he/she wants to achieve, or the means to accomplish what he set out to do. A flexible design or plan is not the same as a lack of plan.

\section{References}

Ahmadian, M., and Rad, S.E. (2014). Postmethod era and glocalized language curriculum development: A fresh burden on language teachers. Journal of Language Teaching and Research, 5(3), 592-598. https://doi.org/10.4304/jltr.5.3.592-598

Bachman, L. F. (1990) Fundamental considerations in language testing. Oxford: Oxford University Press.

Bolívar, A., and Domingo, J. (2006). The professional identity of secondary school teachers in Spain crisis and reconstruction. Theory and Research in Education, 4(3), 339-355. https://doi.org/10.1177/1477878506069105

Brumfit, C. J. (1984). Function and structure of a state school syllabus for learners of second or foreign language with heterogeneous needs. In C.J. Brumfit (ed.). General English syllabus design. Oxford: Pergamon Press, pp. 75-82.

Can, N. (2012). Post-method pedagogy: Teacher growth behind walls. Proceedings of the 10th METU ELT Convention. Available at: http://dbe.metu.edu.tr/convention/proceedingsweb /Pedagogy.pdf (Accessed: 8/10/2014)

Canale, M. (1983). From communicative competence to communicative language pedagogy'. Language and Communication, 1, 1-47.

Chomsky, N. (1965) Aspects of the theory of syntax. Special technical report. Research laboratory of electronics. Cambridge: Massachusetts Institute of Technology (11).

Council of Europe (2001) Common European framework of reference for language learning, teaching and assessment. Cambridge: Cambridge University Press.

Cummins, J. (1979). Linguistic interdependence and the educational development of bilingual children. Review of Educational Research, 49(2), 222-251. https://doi.org/10.3102/00346543049002222

Ehrman, M. E., Leaver, B.L. and Oxford, R. (2003). A brief overview of individual differences in second language learning. System, 31(3), 313-330. https://doi.org/10.1016/S0346-251X(03)00045-9

Farrell, C. (2002). Lesson planning. In J.C. Richards and W.A. Renandya (eds.) Methodology in language teaching: An anthology of current practice. Cambridge: Cambridge University Press, pp. 30-39. https://doi.org/10.1017/CB09780511667190

Fullan, M. (2007) The new meaning of educational change. New York: Routledge.

Graves, K. (2016). Language curriculum design: possibilities and realities. In G. Hall (Ed.). The Routledge handbook of English language teaching. London \& New York: Routledge, pp 79-94.

Hadley, G. (1998) Examining the underlying principles of EFL syllabus design. 敬和学園大学研究紀要, 7, 211228.

Hall, G. (2016). Method, methods and methodology: historical trends and current debates. In G. Hall (ed.). The Routledge handbook of English language teaching. London \& New York: Routledge, pp. 209223.

Hashemi, S. M. R. (2011). (Post)-Methodism: Possibility of the Impossible?'. Journal of Language Teaching \& Research, 2(1), 137-145. https://doi.org/10.4304/jltr.2.1.137-145

Hymes, D. (1967). Models of the interaction of language and social setting. Journal of Social Issues, 23(2), 828. 4560.1967.tb00572.x https://doi.org/10.1111/j.1540-

Kearsley, G. and Lynch, W. (1996). Structural issues in distance education. Journal of Education for Business, 71(4), 191-6. https://doi.org/10.1080/08832323.1996.101167 83

Kumaravadivelu, B. (2001). Toward a postmethod pedagogy. TESOL quarterly, 35(4), 537-560. https://doi.org/10.2307/3588427

Kumaravadivelu, B. (2002). Beyond Methods: Macrostrategies for language teaching. Yale: Yale University Press.

Kumaravadivelu, B. (2006). TESOL methods: Changing tracks, challenging trends. TESOL Quarterly, 40(1), 59-81. https://doi.org/10.2307/40264511

Luque, G. (2017). Syllabus design for pre-service English language teachers in the shifting arena of the continuous Spanish educational reforms. XXXV AESLA Conference. Languages at the crossroads: training, accreditation and context of use. Jaén, May, 4-6.

Nation, P. and Macallister, J. (2009). Language curriculum design. New York: Routledge.

Nunan, D. (1988). Syllabus design. Oxford: Oxford University Press.

Ramos, M.M. and Luque, G. (2010). A competencebased constructivist tool for evaluation. Cultura y $\begin{array}{lll}\text { Educación, } & 22(3), & 329-344 .\end{array}$ https://doi.org/10.1174/113564010804932148

Richards, J.C. (2013). Curriculum approaches in language teaching: Forward, central and backward design. RELC Journal, 44(1), 5-33. https://doi.org/10.1177/0033688212473293

Richards, J.C., and Rodgers, T.S. (2014). Approaches and methods in language teaching. Cambridge: 
Luque Agulló, Gloria (2018). Syllabus Design for Pre-Service English Language Teachers in Spain, @tic revista d'innovació educativa, 20, 26-34.

Cambridge University Press.

https://doi.org/10.1017/CB09780511667305

Skehan, P. (1996). Second language acquisition research and task-based instruction. In J. Willis and D. Willis (eds.) Challenge and change in language teaching. Oxford: Heinemann, pp. 17-30.

Smriti, K. and Jha, S.K. (2015). An overview of ELT syllabi. International Journal of Innovations in TESOL and Applied Linguistics, 1, 1-6.

Tejada, G., Perez, M.L. and Luque, G. (2006). Current approaches and teaching methods. In N. McLaren and D. Madrid (eds.). TEFL in secondary education. Granada: Servicio de publicaciones, pp. 155-209.

Tiana, A., Moya, J. and Luengo, F. (2011). Implementing key competences in basic education: reflections on curriculum design and development in Spain. European Journal of Education, 46(3), 307-322. https://doi.org/10.1111/j.14653435.2011.01482.x

Wang, V. and Stelson, U. (2017). Fundamentals in program development. In V. Wang (ed.) Handbook of Research on Program Development and Assessment Methodologies in K-20 Education. Hershey: IGI Global, pp. 24-48.

White, R. (1988) The ELT curriculum: Design, innovation and management. Oxford: Blackwell.

Widdowson, H.G. (1990) Aspects of language teaching. Oxford: Oxford University Press.
Willis, D., and Willis, J. (2008) Doing task-based teaching. Oxford: Oxford University Press.

Winke, P. M. (2007). The psychology of the language learner: Individual differences in second language acquisition. Studies in Second Language Acquisition, 29(1), 143-144.

Yalden, J. (1983) The communicative syllabus: Evolution, design and implementation. Oxford: Pergamon.

I How to reference this article

Luque Agulló, Gloria (2018). “Syllabus Design for Pre-Service English Language Teachers in Spain”. @tic revista d'innovació educativa, 20, 26-34. 